\title{
Level of Awareness and Use of the Different BIM Software Packages in the Nigerian AEC Industry
}

\author{
Ediae O. J. ${ }^{1}$ and Enoma E. P. ${ }^{2, *}$ \\ ${ }^{1}$ Department of Architecture, College of Science and Technology, Covenant University, Canaanland, Otta, Ogun \\ State, Nigeria \\ ${ }^{2}$ Department of Architecture, Faculty of Environmental Sciences, University of Benin, Benin City, Edo State, \\ Nigeria \\ Corresponding Author: *paul.enoma@ uniben.edu
}

\begin{abstract}
This study considered the extent of use of Building Information Modelling (BIM), in the Architecture, Engineering and Construction Industry (AEC) in Nigeria. The factors influencing the level of adoption of BIM and the barriers to the adoption of BIM in the AEC industry in Nigeria was investigated. The data collection technique used was the survey method, which involved the administration of structured questionnaires to 100 professionals in the AEC industry in Nigeria in the three main cities of Lagos, Port Harcourt, and Abuja. The data was analysed using Statistical Package for the Social Sciences (SPSS). The result shows that most professionals in the AEC Industry are aware of the use of BIM in the AEC Industry and a lot of professionals have also engaged in the use of BIM tools. It also shows that the BIM tools are mostly used for activities in the design stage such as design, visualization and drafting but, are least used for maintenance activities. The major barriers to the adoption of BIM in the AEC Industry in the study include, lack of training and education on BIM use, technical challenges associated with adoption of BIM, the complicated nature and processes involved in BIM use, inadequate government support for BIM use in the AEC Industry and general resistance to change by people in the AEC Industry. The study recommends that in order to achieve critical mass adoption of BIM and its benefits maximized in the AEC Industry in Nigeria there is a need for sensitization on the benefits of BIM and training of students and professionals in the industry on the use of BIM.
\end{abstract}

Keywords: Barriers, Adoption, Industry, Sensitization, Benefits

\subsection{Introduction}

Building information modeling (BIM) has been a growing development within the past few years in the construction industry. The use of BIM has provided a means for increasing total project quality, providing accurate scheduling timetables, yielding quantity takeoffs, and diminishing total project costs (Eastman et al., 2008). The Architecture, Engineering, and Construction (AEC) industry has long sought techniques to decrease project cost, increase productivity and quality, and reduce project delivery time. BIM offers the potential to achieve these objectives (Nadeem et al., 2008). Building Information Model is primarily a three dimensional digital representation of a building as well as its intrinsic characteristics that contains information like architectural design model, construction model, schedule model (4D), cost model (5D), fabrication model and operation model, useful within the construction project industry. BIM is also the process and practice of virtual design and construction throughout the building lifecycle (Hergunsel, 2011).

It is however important to note that Building Information Model is not the same as Building Information Modelling. Building Information Model is a collection of interlinked domain models, sharing all the necessary information for design, construction and maintenance of the building whereas, Building Information Modeling (BIM) is not just a digital model but a process of creating and applying it to the design, planning and execution of construction work (Berard, 2012). Simply 
put, Building Information Modeling is a process of developing Building Information Model. Generally, BIM is more than drawings - it is a data repository for building design, construction and maintenance information combined in one convenient model to be shared with all the stakeholders. It is a technology as well as a process and can display the entire life cycle of a building project (Gardezi et al, 2014).

Quantities and shared properties of materials can be extracted easily. Scopes of work can be isolated and defined. Systems, assemblies and sequences can be shown in a relative scale with the entire facility or group of facilities. BIM also prevents errors by enabling conflict or 'clash detection' whereby the computer model visually highlights to the team where parts of the building (e.g. structural frame and building services pipes or ducts) may wrongly intersect (Srivastava, 2016). BIM helps to reduce information loss which occurs when a design project is transferred from design team, to construction team and to building owner/operator, by allowing each group to add to and reference back to all information they acquired during their period of contribution to the BIM model. This can yield benefits to the facility owner or operator (Srivastava, 2016). Dynamic information about the building, such as sensor measurements and control signals from the building systems, can also be incorporated within BIM software to support analysis of building operation and maintenance as described by (Liu and Akinci, 2009).

There is a general lack of studies on the adoption of BIM in the AEC industry in Nigeria. A recent study by Ezeokoli et al. (2016) looked at the factors affecting the adaptability of BIM for construction projects. However, their study was only focused on Anambra State. This study aims to look at the adoption of BIM in the AEC industry in Nigeria, with a view to suggesting how to achieve a critical mass uptake.

\subsection{Methodology}

The survey method was adopted, through the administration of structured questionnaire to respondents to enable the researchers to reach a large number of the target population in a very short time and ensure uniformity in questions posed to the respondents. Data were collected from surveys of architects, engineers, contractors and other allied professionals in the AEC industry in Nigeria, for three main cities - Lagos, Port Harcourt, and Abuja. Sampling size ranged from (60-70) participants in Lagos (15-20), participants in Abuja and (10-15) participants in Port-Harcourt. These were randomly selected and more participants were selected from the City of Lagos due to proximity to researchers and accessibility. Although 120 questionnaires were distributed to respondents in the three aforementioned Cities, only 100 questionnaires were retrieved. This represents $83 \%$ response rate. However, 98\% of the retrieved questionnaires were valid and were analysed with, the use of Statistical Package for the Social Sciences (SPSS).

\subsection{Results and Discussion}

\subsection{Role of the respondents in the AEC industry}

Table 1 shows the result of the analysis of data of the respondents' role in the AEC industry.

Table 1: The respondents' role in the AEC Industry

\begin{tabular}{|l|l|l|}
\hline Role of the Respondents & Frequency $(\mathrm{n}=98)$ & Percent \\
\hline Architect & 40 & 40.8 \\
\hline Builder & 4 & 4.1 \\
\hline Engineer & 30 & 30.6 \\
\hline Contractor & 3 & 3.1 \\
\hline Construction/Project manager & 2 & 2.0 \\
\hline Quantity surveyor & 14 & 14.3 \\
\hline Facility managers & 3 & 3.1 \\
\hline Estate Surveyor & 3 & 3.1 \\
\hline Academic Staff & 1 & 1.0 \\
\hline \multicolumn{2}{|l|}{ Source: Researchers' field survey } \\
\end{tabular}

Source: Researchers' field survey 
It is evident from Table 1 that the highest number of respondents in the survey were architects, who constitute around $41 \%$ of those sampled, followed by engineers $31 \%$, and quantity surveyors $14 \%$, respectively. The least was those in the academics, who represent about one percent of the participants in this research. The result shows that, majority of professionals in the AEC industry in Nigeria participated in this research.

\subsection{The respondents' organizations}

Table 2 shows the different types of organizations the respondents were employed in at the time of the survey. Examination of the result (Table 2) reveals that around $44.4 \%$ of the respondents were employed in consulting firms, $36.4 \%$ were employed in academic/research institutions, $9.1 \%$ in client organizations and another $9.1 \%$ were employees of construction firms. However, only around one percent of the participants indicated that they were employees of Government Ministries/Parastatals/Departments. This result clearly shows that the highest number of participants in this research were employees of consulting firms, while the least number were employees of government institutions.

Table 2: The respondents' organizations

\begin{tabular}{|l|l|l|}
\hline Role of the Respondents & Frequency $(\mathrm{n}=98)$ & Percent \\
\hline Academic reseacrh Institution & 36.4 & 36.36 \\
\hline Consulting firm & 44.4 & 44.44 \\
\hline Contractor & 9.1 & 9.09 \\
\hline Client Organisation Government & 9.1 & 9.09 \\
\hline Ministry/Parastatal/Department & 1 & 1.01 \\
\hline \multicolumn{2}{|l}{ Source: Researchers' field survey }
\end{tabular}

\subsection{Highest educational qualification of the respondents}

The result on the respondents highest educational qualifications are displayed in Table 3.

Table 3: Respondents' highest educational qualification

\begin{tabular}{|l|l|l|}
\hline Role of the Respondents & Frequency $(\mathrm{n}=98)$ & Percent \\
\hline Master's & 43.4 & 44 \\
\hline Ph.D Degree & 10.1 & 10 \\
\hline Postgraduate Diploma & 2 & 2 \\
\hline Others & 1 & 1 \\
\hline National Diploma & 2 & 2 \\
\hline Higher National Diploma & 11.1 & 11 \\
\hline Bachelor Degree & 29.3 & 30 \\
\hline
\end{tabular}

Source: Researchers' Field Survey

It can be seen in Table 3 that around $44 \%$ of the respondents are Master degree holders, $30 \%$ of them had bachelor degree, while $11 \%$ and $10 \%$ had Higher National Diploma (HND) and Ph.D. respectively. The result also shows that National Diploma holders constitute around 2\% of the sample and another $2 \%$ of the participants were those who had Postgraduate Diploma as their highest educational qualification. This result indicates that the highest number of those who took part in the survey had master's degree, while the least had unclassified qualifications. It is therefore evident from the data in Table 3 that the respondents in the survey are highly educated individuals.

\subsection{Professional registration status of the respondents}

Regarding the professional registration status of the respondents, Figure 1 shows the distribution of the participants in the research according to their professional registration status. From the result displayed in Figure 1, it is evident that a majority of the respondents were not registered by the different professional bodies in Nigeria at the time of the survey. However, $23 \%$ of the respondents were registered with the Architects Registration Council of Nigeria (ARCON), 17\% were registered with the Council of Registered Engineers of Nigeria (COREN), while 2\% were registered by Estate Surveyors and Valuers Registration Board of Nigeria (ESVRABON). This result suggests that most of those sampled in this study were yet to secure full registration with respective bodies established to regulate the practice of their different professions in Nigeria. This means that a majority of 
participants in this research are not licensed to practice their different professions they were trained to practice, suggesting that they are not professionals in other fields.

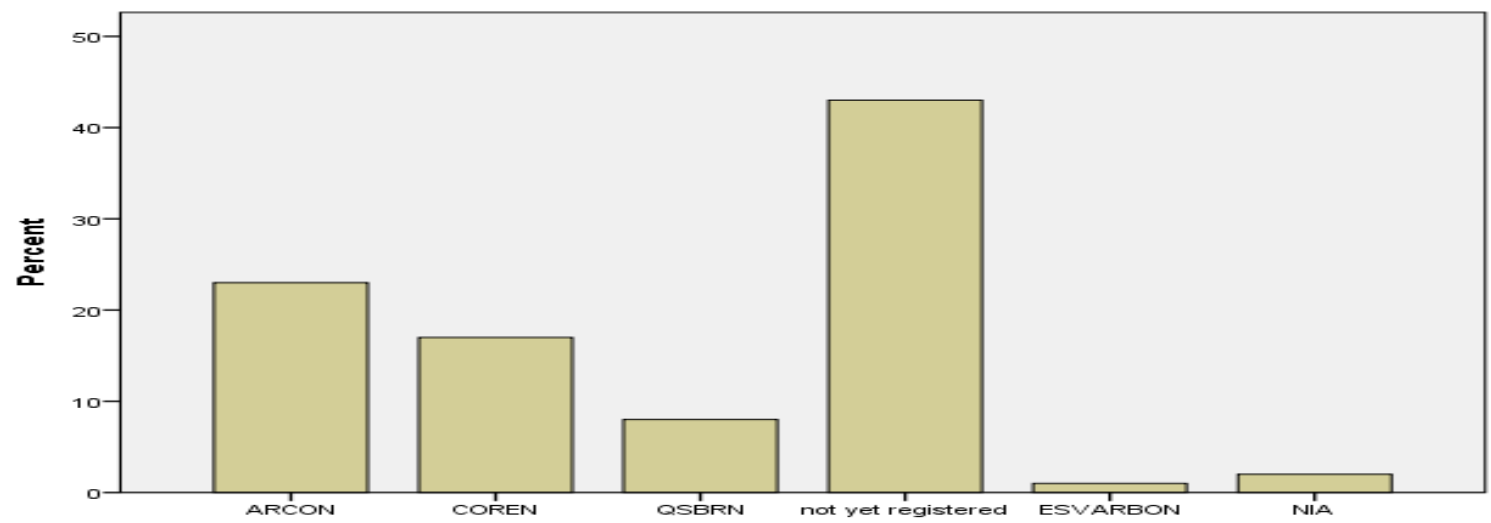

Figure 1: Professional registration status of the respondents

Source: Researchers' Field Survey

\subsection{Years of practical experience in the industry}

The researchers also collected data on the number of years of practical experience of the respondents in the survey. The result is as shown in Figure 2.

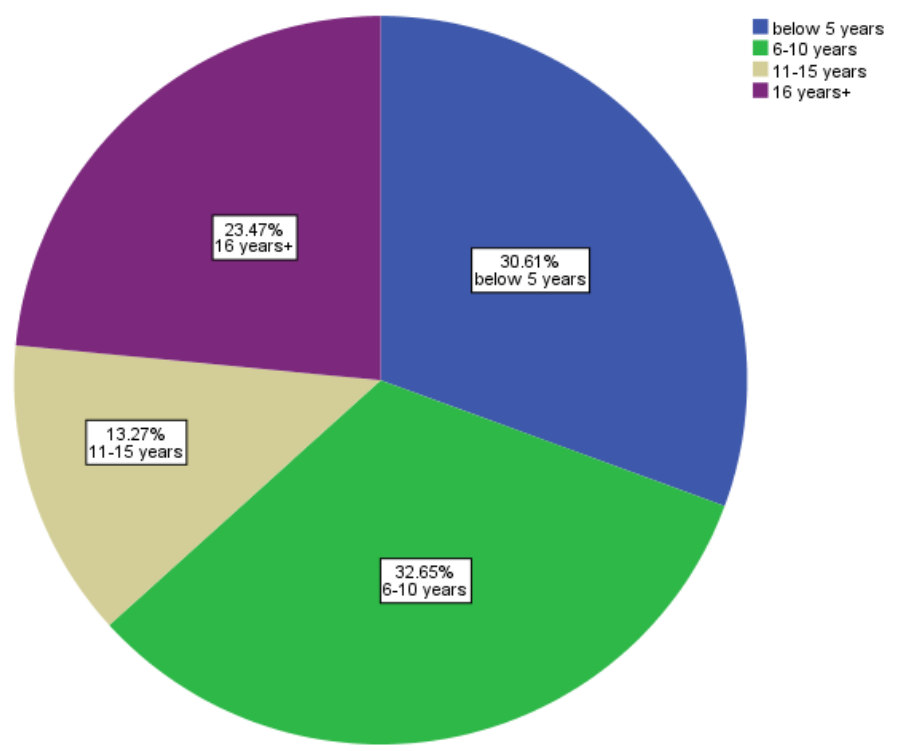

Figure 2: Years of practical experience

Source: Researchers' Field Survey

The result in Figure 2 shows that around $31 \%$ of the respondents have less than 5 years of practical experience in the field, around 33\% had practical experience of between 6 years and 10 years, $13 \%$ have between 11 years and 15 years practical experience, while around $24 \%$ had over 15 years of practical experience. This result suggests that a high majority of the participants have over years of practical experience in the field. Therefore, they can be considered well experience individuals who are qualified to provide reliable data for this research.

\subsection{Respondents' role in their organizations}

Table 4 shows the result of the respondents' specific roles in their different organizations. From Table 4 it is evident that around $18 \%$ of the respondents were architects, 9\% were academic Staff and Managing Directors, while the least number of them were, Principals \& Lecturers, Quantity Surveyors, Principal Officers, Managers, Industrial Trainees and Consultants. This result shows that the participants in the research were drawn from the different cadres of employees in the different organizations. 
Table 4: Respondents' role in their organizations

\begin{tabular}{|l|l|l|}
\hline Role & Frequency & Percent \\
\hline Academic Staff & 9 & 9.0 \\
\hline Architect & 18 & 18.0 \\
\hline Assistant Quantity Surveyor & 4 & 4.0 \\
\hline Civil Engineer & 3 & 3.0 \\
\hline Consultant & 1 & 1.0 \\
\hline Consulting Electrical Engineer & 2 & 2.0 \\
\hline Deputy Manager & 2 & 2.0 \\
\hline Design Engineer & 2 & 2.0 \\
\hline Director & 5 & 5.0 \\
\hline Electrical Engineer & 2 & 2.0 \\
\hline Estate Officer & 2 & 2.0 \\
\hline Facility Manager & 7 & 7.0 \\
\hline Industrial Trainee & 1 & 1.0 \\
\hline Junior Engineer & 2 & 2.0 \\
\hline Manager & 1 & 1.0 \\
\hline Managing Director & 9 & 9.0 \\
\hline Partners & 7 & 7.0 \\
\hline Principal \& Lecturer & 1 & 1.0 \\
\hline Principal Officer & 1 & 1.0 \\
\hline Property Management Officer & 2 & 2.0 \\
\hline Quantity Surveyor & 1 & 1.0 \\
\hline Senior Officer & 4 & 4.0 \\
\hline Site/Structural Engineer & 2 & 2.0 \\
\hline Source: Researchers & &
\end{tabular}

Source: Researchers' Field Survey

\subsection{Numbers of offices the respondents' organizations have in Nigeria}

The study also investigated the number of offices the respondents' organization have in Nigeria. The result is as presented in Figure 3.

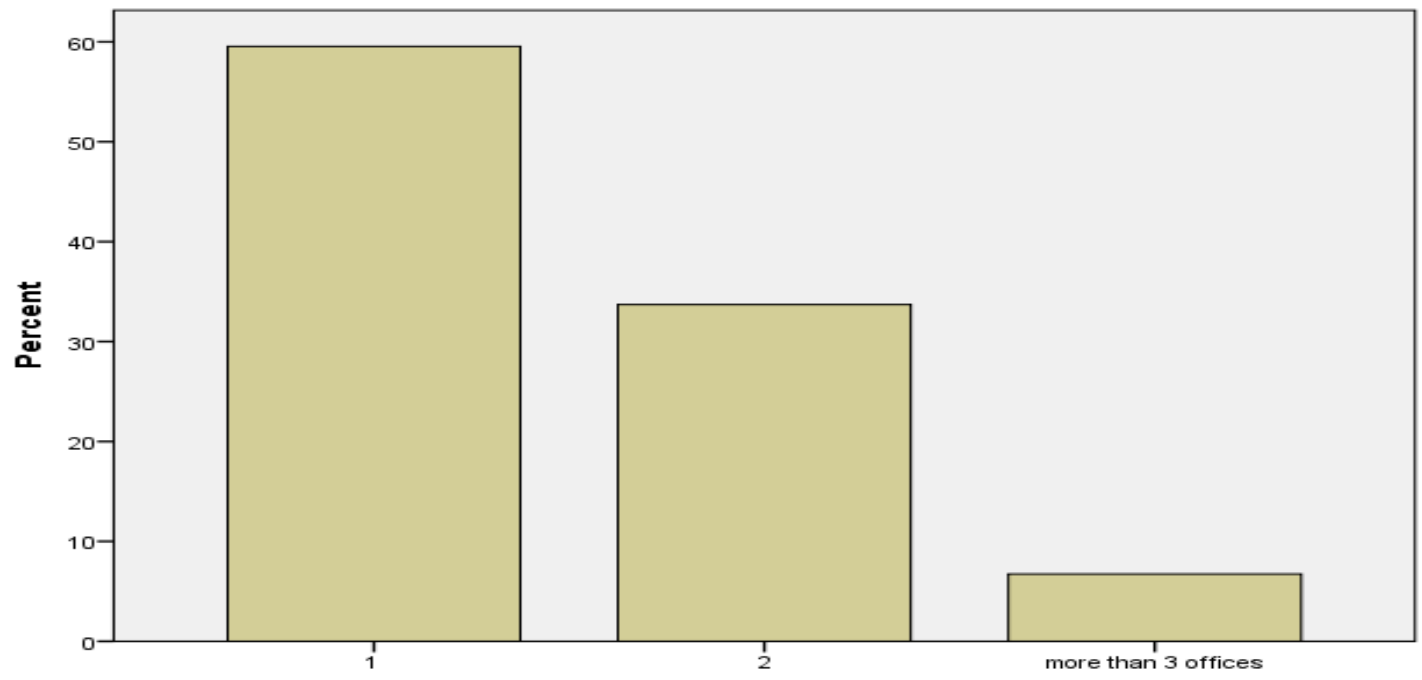

Figure 3: The number offices respondents' organizations have in Nigeria

Source: Researchers' Field Survey

From the result in Figure 3, it is evident that most of the respondents' organizations had one office in Nigeria; about $34 \%$ had 2 offices, while $7 \%$ of the respondents' organizations had more than 3 offices in Nigeria. Based on this result, it can be inferred that most of the organizations where the respondents were employed can be regarded as Small, Medium and Micro-Sized Enterprises (SMMEs).

\subsection{Sex of the Respondents}

The result on the sex of the respondents reveals that majority $82(82 \%)$ of the respondents were male, while $18(18 \%)$ were female. This result is understandable as the AEC industry is usually and known to be male dominated globally. 


\subsection{Use of BIM-based software package}

From data collected and as represented in (Figure 4), the level of awareness of the use of BIM in the AEC industry is very high. In addition to investigating the level of awareness of the use of BIM in the architecture, engineering and construction industry, the respondents were also asked to indicate whether they had used any BIM software package in their work. The result is as presented in Figure 4. It is evident from the result (Figure 4) that of the 96 respondents who are aware of BIM, $74(77 \%)$ of them indicated that they use BIM-based software package relating to their field, while $22(23 \%)$ of them had never used any BIM software package in their work.

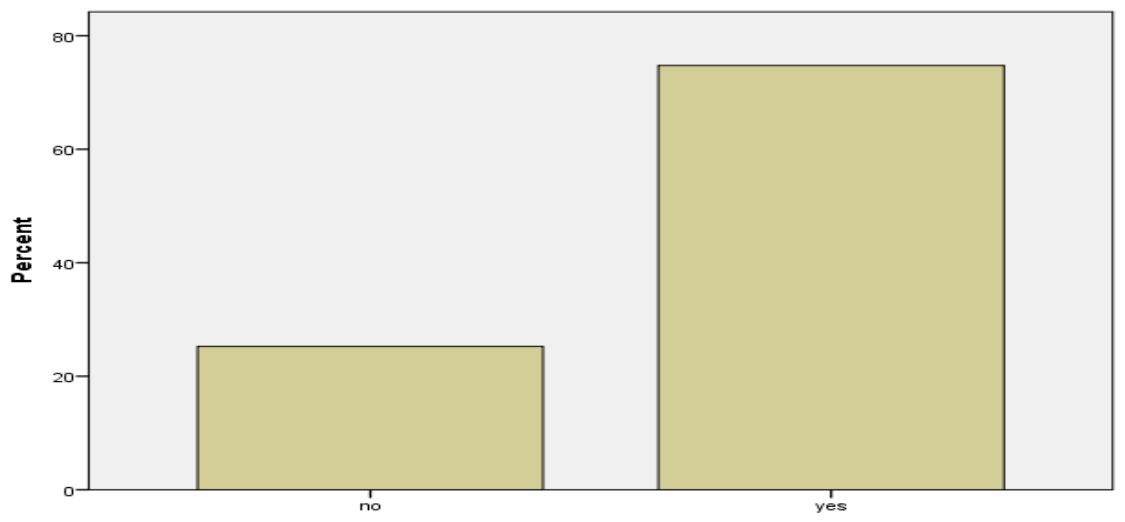

Figure 4: Use of BIM-based software package

Source: Researchers' Field Survey

The result in Figure 4 clearly shows that majority of the participants have used one BIM software package or the other in their works. This suggests that there is a high level of adoption of BIM among the respondents in the survey.

\subsection{The Different BIM Software Packages used by the Respondents}

The result of the different BIM software applications used by the respondents is also presented in Table 5. It is evident in Table 5 that a majority (81\%) used Autodesk Revit Architecture, followed by around 34\% who used AUTOCAD, 21.4\% that used Graphisoft ArchiCAD and 14\% that used Autodesk Revit Structure. The least, around one percent used Bentley Architecture, Bentley Structural and StaadPro respectively. This result is an indication that the most commonly used BIM software by the participants of this research is Autodesk Revit Architecture. This is not a surprise as many of the participants are architects.

Table 5: BIM software packages used by the respondents

\begin{tabular}{|l|l|l|}
\hline BIM software packages & Frequency & Percent \\
\hline Autodesk Revit architecture & 57 & 81.4 \\
\hline Autodesk Revit structure & 10 & 14.3 \\
\hline Autodesk Revit MEP & 9 & 12.9 \\
\hline Bentley Architecture & 1 & 1.4 \\
\hline Bentley structural & 1 & 1.4 \\
\hline Graphisoft ArchiCAD & 15 & 21.4 \\
\hline Telka & 4 & 5.7 \\
\hline Digital Project Designer & 2 & 2.9 \\
\hline AutoCAD & 24 & 34.3 \\
\hline 3dsMax & 2 & 2.9 \\
\hline Master Bill & 2 & 2.9 \\
\hline Staad pro & 1 & 1.4 \\
\hline Source: Researchers $f i e l d ~$ & &
\end{tabular}

Source: Researchers' field survey

\subsection{Stages in AEC work where BIM is used}

The respondents were asked to identify the stages in their works where they use BIM. The result in Table 5 shows that around $72(94 \%)$ of them said they use BIM at the design stage, $20 \%$ use it at project execution stage, $13 \%$ at renovation and around $7 \%$ use it at operation stages. However, around $5.2 \%$ indicated that they used BIM at the maintenance stage of their projects. It is evident from 
the result in Table 6 that most of the respondents use BIM most at the design stage and least at the maintenance stage. This suggests that most of the respondents see BIM mainly as a design tool.

Table 6: Stages in construction practices where BIM is used

\begin{tabular}{|l|l|l|}
\hline Stages & Frequency & Percent \\
\hline Design & 72 & 93.5 \\
\hline Execution & 15 & 19.5 \\
\hline Operation & 5 & 6.5 \\
\hline Maintenance & 4 & 5.2 \\
\hline Renovation & 10 & 13.0 \\
\hline
\end{tabular}

Source: Researchers' field survey

\subsection{Extent of use of BIM in executing design tasks}

The study also investigated the extent of use of BIM in executing different aspects of design tasks by the respondents. From the result in Table 7 it is evident that most of the respondents strongly agree to the use of BIM in detail design, most of the respondents also strongly agree to the use of BIM in visualization, most of the respondents agree to the use of BIM in drafting, most of the respondents are undecided in the use of BIM in fabrication/shop drawings, most of the respondents strongly agree to the use of BIM in design review, most of the respondents agree to the use of BIM in design auditing and most of the respondents Strongly agree to the use of BIM in site utilization planning. This clearly shows that most of the respondent use BIM in executing various design tasks.

Table 7: Execution of task in design stage

\begin{tabular}{|c|c|c|c|c|c|c|}
\hline Task & & $\begin{array}{l}\text { Strongly } \\
\text { Disagree }\end{array}$ & Disagree & Undecided & Agree & Strongly Agree \\
\hline \multirow[t]{2}{*}{ Detail Design } & Count & 9 & 4 & 6 & 29 & 35 \\
\hline & Percent & 10.8 & 4.8 & 7.2 & 34.9 & 42.2 \\
\hline \multirow[t]{2}{*}{ Visualization } & Count & 4 & 9 & 8 & 25 & 37 \\
\hline & Percent & 4.8 & 10.8 & 9.6 & 30.1 & 44.6 \\
\hline \multirow[t]{2}{*}{ Drafting } & Count & 4 & 11 & 6 & 35 & 23 \\
\hline & Percent & 5.1 & 13.9 & 7.6 & 44.3 & 29.1 \\
\hline \multirow{2}{*}{$\begin{array}{l}\text { Fabrication/Shop } \\
\text { Drawings }\end{array}$} & Count & 8 & 12 & 23 & 17 & 21 \\
\hline & Percent & 9.9 & 14.8 & 28.4 & 21.0 & 25.9 \\
\hline \multirow[t]{2}{*}{ Design Reviews } & Count & 9 & 6 & 14 & 22 & 29 \\
\hline & Percent & 11.3 & 7.5 & 17.5 & 27.5 & 36.3 \\
\hline \multirow[t]{2}{*}{ Design Auditing } & Count & 9 & 0 & 23 & 27 & 17 \\
\hline & Percent & 11.8 & 0.0 & 30.3 & 35.5 & 22.4 \\
\hline \multirow[t]{2}{*}{ Site Utilization Planning } & Count & 4 & 11 & 16 & 22 & 24 \\
\hline & Percent & 5.2 & 14.3 & 20.8 & 28.6 & 31.2 \\
\hline
\end{tabular}

Source: Researchers' Field Survey

\subsection{Extent of Use of BIM in Analysis Related Tasks}

The result in Table 8 is the extent of use of BIM in executing analysis related tasks by the participants in the research.

Table 8: Extent of use of BIM in analysis related tasks

\begin{tabular}{|c|c|c|c|c|c|c|}
\hline Task & & $\begin{array}{l}\text { Strongly } \\
\text { Disagree }\end{array}$ & Disagree & Undecided & Agree & $\begin{array}{l}\text { Strongly } \\
\text { Agree }\end{array}$ \\
\hline \multirow{2}{*}{$\begin{array}{l}\text { Analysis of potential } \\
\text { failures, leaks, } \\
\text { evacuation plans }\end{array}$} & Count & 10 & 18 & 19 & 16 & 14 \\
\hline & Percent & 13.0 & 23.4 & 24.7 & 20.8 & 18.2 \\
\hline \multirow{2}{*}{$\begin{array}{l}\text { Building system } \\
\text { analysis }\end{array}$} & Count & 7 & 5 & 25 & 29 & 13 \\
\hline & Percent & 8.8 & 6.3 & 31.3 & 36.3 & 16.3 \\
\hline \multirow[t]{2}{*}{ Simulation } & Count & 6 & 19 & 19 & 30 & 4 \\
\hline & Percent & 7.7 & 24.4 & 24.4 & 38.5 & 5.1 \\
\hline \multirow[t]{2}{*}{ Energy analyses } & Count & 13 & 9 & 20 & 26 & 6 \\
\hline & Percent & 17.6 & 12.2 & 27.0 & 35.1 & 8.1 \\
\hline \multirow{2}{*}{$\begin{array}{l}\text { Building } \\
\text { performance analysis }\end{array}$} & Count & 19 & 6 & 26 & 18 & 11 \\
\hline & Percent & 23.8 & 7.5 & 32.5 & 22.5 & 13.8 \\
\hline \multirow{2}{*}{$\begin{array}{l}\text { Interrogation of } \\
\text { different models }\end{array}$} & Count & 2 & 25 & 11 & 30 & 10 \\
\hline & Percent & 2.6 & 32.1 & 14.1 & 38.5 & 12.8 \\
\hline
\end{tabular}

Source: Researchers' Field Survey 
It is evident from Table 8 that, only $30(39 \%)$ of the BIM users claimed that they use BIM in the analysis of potential failures, leaks and evacuation plan, around 53\% use BIM to conduct building systems analysis, $44 \%$ use it for simulation, while around $43.2 \%$ use BIM for energy analysis. The result further shows that around $36.3 \%$ use BIM to conduct building performance analysis and $51.3 \%$ use BIM to interrogate different building models. It is clear from this result that comparatively, in terms of analyses, a majority of the users seems to use BIM in executing activities related to building systems analyses and building performance analysis, while just about one-third of the respondents used BIM to identify and analyse potential failures, leaks and evacuation plan in buildings. Therefore, it can be inferred form this result that, the participants in the research, used BIM more for building systems and performance analyses than any other types of analyses.

\subsection{Extent of use of BIM in project cost analysis}

Regarding the extent of use of BIM in project cost analysis, the result is as shown in Table 9.

Table 9: Use of BIM in project cost analysis

\begin{tabular}{|l|l|l|l|l|l|l|}
\hline \multicolumn{2}{|l|}{ Task } & $\begin{array}{l}\text { Strongly } \\
\text { Disagree }\end{array}$ & Disagree & Undecided & Agree & Strongly Agree \\
\hline \multirow{2}{*}{ Quantity take-off } & Count & 10 & 14 & 15 & 22 & 19 \\
\cline { 2 - 8 } & Percent & 12.5 & 17.5 & 18.8 & 27.5 & 23.8 \\
\hline \multirow{2}{*}{ Cost estimating } & Count & 7 & 10 & 22 & 24 & 18 \\
\cline { 2 - 8 } & Percent & 8.6 & 12.3 & 27.2 & 29.6 & 22.2 \\
\hline
\end{tabular}

Source: Researchers' Field Survey

From the results in Table 9, it can be observed that most (51.3\%) of the respondents use BIM in Quantity take-off and around 52\% of them used it in Cost Estimating. This suggests that a little above average of those who indicated that they have used BIM, used it to execute task associated with project cost estimating and analysis.

\subsection{Extent of use of BIM in e-procurement}

The study also investigated the extent of use of BIM in supporting the execution of e-procurement tasks by the respondents. The result is as presented in Table 10.

Table 10: Extent of Use of BIM in e-procurement

\begin{tabular}{|l|l|l|l|l|l|l|}
\hline Task & & $\begin{array}{l}\text { Strongly } \\
\text { Disagree }\end{array}$ & Disagree & Undecided & Agree & $\begin{array}{l}\text { Strongly } \\
\text { Agree }\end{array}$ \\
\hline $\begin{array}{l}\text { Create material ordering, } \\
\text { fabrication and delivery } \\
\text { schedules for all building } \\
\text { components(i.e. construction } \\
\text { sequencing) }\end{array}$ & Peunt & 15 & 3 & 17 & 31 & 14 \\
\hline Electronic (e-) procurement & 18.8 & 3.8 & 21.3 & 38.8 & 17.5 \\
\cline { 2 - 8 } & Count & 15 & & & & \\
\end{tabular}

Source: Researchers' Field Survey

From the result in Table 10, it can be observed that whereas most $(56.3 \%)$ of the respondents indicated that, they used BIM to create material ordering, fabrication and delivery schedules for all building components, around $48 \%$ said they used BIM in e-Procurement activities. This means that most of the respondents do not use BIM to support the execution of e-Procurement activities.

\subsection{Extent of use of BIM in executing renovation/maintenance tasks}

Table 11 is the display of the result on the use of BIM in renovation and maintenance tasks by the respondents. It can be seen in Table 11 that whereas a majority (64\%) of the respondents claimed to use BIM to support the execution of tasks related to renovations, space planning and maintenance operations, around 52\% said that, they use BIM for maintenance scheduling. This result suggests that most of the participants in this research actually use BIM to support the execution of tasks associated with renovation and maintenance of buildings and related facilities. 
Table 11: The Use of BIM in Maintenance Operation

\begin{tabular}{|l|l|l|l|l|l|l|}
\hline \multicolumn{2}{|l|}{ Task } & $\begin{array}{l}\text { Strongly } \\
\text { Disagree }\end{array}$ & Disagree & Undecided & Agree & Strongly Agree \\
\hline $\begin{array}{l}\text { Renovations, space } \\
\text { planning and } \\
\text { maintenance operations }\end{array}$ & Count & 5 & 8 & 16 & 30 & 21 \\
\cline { 2 - 8 } & Percent & 6.3 & 10.0 & 20.0 & 37.5 & 26.3 \\
\hline Maintenance scheduling & Count & 9 & 6 & 23 & 23 & 18 \\
\cline { 2 - 8 } & Percent & 11.4 & 7.6 & 29.1 & 29.1 & 22.8 \\
\hline
\end{tabular}

Source: Researchers' Field Survey

\subsection{Extent of Use of BIM in Sundry Tasks}

On the extent of use of BIM to support the execution of several other tasks like information integration, problem recording, conflict, interference and collision detection; code validation; crossdiscipline coordination of tasks and tracking of problem resolution, the result is as presented in Table 12.

Table 12: Execution of sundry activities

\begin{tabular}{|c|c|c|c|c|c|c|}
\hline \multicolumn{2}{|l|}{ Task } & $\begin{array}{l}\text { Strongly } \\
\text { Disagree }\end{array}$ & Disagree & Undecided & Agree & $\begin{array}{l}\text { Strongly } \\
\text { Agree }\end{array}$ \\
\hline \multirow[t]{2}{*}{ Information integration } & Count & 16 & 8 & 13 & 25 & 12 \\
\hline & Percent & 21.6 & 10.8 & 17.6 & 33.8 & 16.2 \\
\hline \multirow{2}{*}{ Problem Recording } & Count & 11 & 8 & 25 & 19 & 10 \\
\hline & Percent & 15.1 & 11.0 & 34.2 & 26.0 & 13.7 \\
\hline \multirow{2}{*}{$\begin{array}{l}\text { Conflict, interference and collision } \\
\text { detection (i.e. clash detection) }\end{array}$} & Count & 14 & 11 & 26 & 23 & 7 \\
\hline & Percent & 17.3 & 13.6 & 32.1 & 28.4 & 8.6 \\
\hline \multirow[t]{2}{*}{ Code Validation } & Count & 18 & 7 & 15 & 22 & 15 \\
\hline & Percent & 23.4 & $9.1 \%$ & 19.5 & 28.6 & 19.5 \\
\hline \multirow{2}{*}{$\begin{array}{l}\text { Cross-discipline coordination of } \\
\text { tasks }\end{array}$} & Count & 15 & 12 & 14 & 26 & 13 \\
\hline & Percent & 18.8 & 15.0 & 17.5 & 32.5 & 16.3 \\
\hline \multirow[t]{2}{*}{ Tracking of problem resolution } & Count & 4 & 18 & 22 & 21 & 8 \\
\hline & Percent & 5.5 & 24.7 & 30.1 & 28.8 & 11.0 \\
\hline
\end{tabular}

Source: Researchers' Field Survey

From the results in Table 12, it is evident that, half (50\%) of the respondents agreed that they use BIM in information integration, $40 \%$ used it in problem recording; $37 \%$ in detecting conflict, interference and collision, $48.1 \%$ use BIM in code validation; around $49 \%$ use BIM in cross-discipline coordination of tasks, while around $40 \%$ of the respondents indicated that they use BIM in tracking problem resolution. This result means that whereas the use of BIM to integrate information appears to be common amongst those sampled in the survey; the use of BIM in problem recording, conflict, interference and collision detection; code validation; cross-discipline coordination of tasks and tracking of problem resolution is not very popular among the respondents in the survey. In fact, only around $37 \%$ of the users indicated that they use BIM in detecting conflict, interference and collision (i.e. clash detection) while $40 \%$ use BIM in tracking problem resolution.

\subsection{Discussion}

\section{BIM software packages used in the Nigerian AEC industry:}

Ezeokoli et al. (2016), observed that compatibility between software platforms, level of knowledge awareness, structure/culture of the industry, non-availability of the appropriate technology and infrastructure, and cost of implementation, individual/personal disposition and lack of BIM standards/guidelines are the reasons why most BIM potential remains untapped in Anambra State.

Twelve BIM software packages were investigated. The result revealed that the most commonly used BIM software package by the respondents is Autodesk Revit Architecture. This is followed by AUTOCAD, Graphisoft ArchiCAD and Autodesk Revit Structure respectively. This result is an indication that AUTODESK Revit Architecture is the most common BIM package used in the Nigerian AEC. The emergence of Autodesk Revit Architecture, AUTOCAD, Graphisoft ArchiCAD and Autodesk Revit Structure as the most commonly used BIM packages in this research did not come as a surprise because, majority of the respondents in the survey are architects, engineers and quantity surveyors and these packages are mostly used by these professionals in the AEC industry. 


\section{Extent of use of BIM in the Nigerian AEC industry:}

From the result of the analysis of the data obtained from the field work, it was observed that, of the 96 respondents who are aware of BIM, 74 of them, representing around $77 \%$ claimed that they actually use BIM in their different fields. This suggests a very high percentage of BIM adoption in the Nigerian AEC industry. It also suggests that high level of awareness of BIM can also translates to high level of adoption of BIM in the industry. Regarding the extent of use of these software packages in the various stages of work in the AEC industry, the study found out that although, it appears that the respondents use BIM across the various stages of project execution, there is a predominant use of BIM at the design stage. This is followed by the use of BIM at the execution stage as well as maintenance/renovation stage. However, in spite of the enormous benefits of BIM at the operational stage of buildings as noted by Srivastava (2016), it is obvious from this study that BIM is rarely used in the operation stage of constructed facilities in the study area.

On the use of BIM tools for specific assignments, the study found the use of BIM in detail design, visualization, drafting, preparation of fabrication/shop drawings, design review, design auditing and preparation of site utilization planning to be very common among the respondents. This means that there is predominant use of BIM as design and drafting tool among the respondents. Further, in the use of BIM to support the execution of analysis-related tasks, it was also observed that there is predominant use of BIM in building systems and performance analyses as indicated previously by (Liu and Akinci, 2009). However, in spite of the benefits of BIM in clash detection as explained by Srivastava (2016), only about one-third of the respondents used BIM to identify and analyse potential failures, leaks and evacuation plan in buildings. In addition, the study found extensive use of BIM in project cost analysis and estimation; and in maintenance/renovation work, but very low utilization of BIM in e-Procurement and other sundry activities like in tracking problem resolution and clash detection.

\subsection{Conclusion}

Based on the findings, the following conclusions are arrived at. There is a high level of awareness of BIM in the Nigerian AEC industry. There is also a high level of use of BIM software packages among the participants of this research. The most commonly used BIM software packages by the respondents are; the Autodesk Revit Architecture, AUTOCAD and Graphisoft ArchiCAD.

In line with the findings of this research, to achieve a critical mass adoption of BIM and maximise its benefit in the Nigerian AEC industry, there is a need for sensitization on the importance of BIM by professional associations such as the Nigerian Institute of Architects (NIA) and Nigerian Society of Engineers as well as other professional bodies in the building industry. Secondly, more institutions of higher learning need to include the use of BIM in their curriculum. There is also need for workshops, conferences and other capacity building trainings on BIM. Professional Associations in the AEC industry can collaborate with training Institutes and Universities to organize such trainings for Students, Professional and other stakeholders in the industry. These can help address the issue of low knowledge base and skill in BIM. Lastly, government at all levels also need to support the industry by providing sound policy framework that favours the adoption of BIM.

\section{References}

Berard, O. (2012). Building Information Modelling for Managing Design and Construction-Assessing Design Information Quality. PhD Thesis, Denmark Technical University, Civil Engineering. Brovej, Denmark: Department of Civil Engineering Report R-272, 2012

Eastman, C., Teicholz, P., Sacks, R. and Liston, K. (2008). BIM Handbook: A Guide to Building Information Modelling for Owners, Managers, Designers, Engineers and Contractors. New York: John Wiley and Sons.

Ezeokoli, F. O., Nkeleme, E. and Okoye, U. (2016). Factors Affecting the Adaptibiliy of Building Information Modelling (BIM) for Construction Projects in Anambra State Nigeria. Journal of Scientific Research and Reports, 11(5), pp. 1-10. 
Gardezi, S. S., Shafiq, N., Nurudinn M. F., Farhan, S. A. and Umar, U. A. (2014). Challenges for Implementation of Buiding Information Modelling (BIM) in Malaysian Construction Industry. Applied Mechanics and Materials, 567, pp. 559-564.

Hergunsel, M. F. (2011). Benefits of Building Information Modelling for Construction Managers and BIM based scheduling, published M.Sc. Thesis, Worcester Polytechnic Institute, Worcester; 2011.

Liu, X. and Akinci, B. (2009). Requirements and Evaluation of Standards for Integration of Sensor Data with Building Information Models. In: C. H, O'Brien, \& W. J, Computing in Civil Engineering (pp. 95-104). American Society of Civil Engineers.

Nadeem, A., Azhar, S. and Mok, J. Y. (2008). Building information modeling (BIM): A new paradigm for visual interactive modelling and simulation for construction projects. First International Conference on Construction in Developing Countries (ICCIDC-I), (pp. 435-446). Karachi, Pakistan.

Srivastava, S. (2016). Administration of Construction Contracts. Chennai: Notion Press. 